\title{
Sponsored multicentric clinical research conducted in Brazil in the respiratory area - losses and gains
}

\author{
Andréa Kelly da Silveira Carvalho ${ }^{1 *}$, Oliver Augusto Nascimento ${ }^{2}$, Marcelo Cunio Machado Fonseca ${ }^{3}$, Eanes Delgado \\ Barros Pereira ${ }^{4}$, José Roberto Jardim ${ }^{5}$ \\ ${ }^{1} \mathrm{PhD}$ - Visiting Professor of the Graduate Program in Cardiorespiratory Physiotherapy at Universidade de Fortaleza (Unifor) | Project Manager at xlung/Pulmocenter, Fortaleza, CE, Brazil \\ ${ }^{2} \mathrm{MD}$, PhD - Pulmonology Department, Universidade Federal de São Paulo (Unifesp). Vice-director of the Pulmonary Rehabilitation Center, Unifesp, São Paulo, SP, Brazil \\ ${ }^{3} \mathrm{MSC}$ - Cabinet Chief Advisor to the President's Office at Unifesp. Coordinator of the Technology Assessment Service, Women's Health Area, Gynecology Department at Unifesp, São Paulo, SP, Brazi \\ ${ }^{4} \mathrm{PhD}$ - Associate Professor, Internal Medicine Department, Universidade Federal do Ceará (UFC), Fortaleza, CE, Brazil \\ ${ }^{5}$ Habilitation (BR: Livre-docência) - Associate Professor of Pneumology, Escola Paulista de Medicina - Unifesp. Director of the Pulmonary Rehabilitation Center, Unifesp, São Paulo, SP, Brazil
}

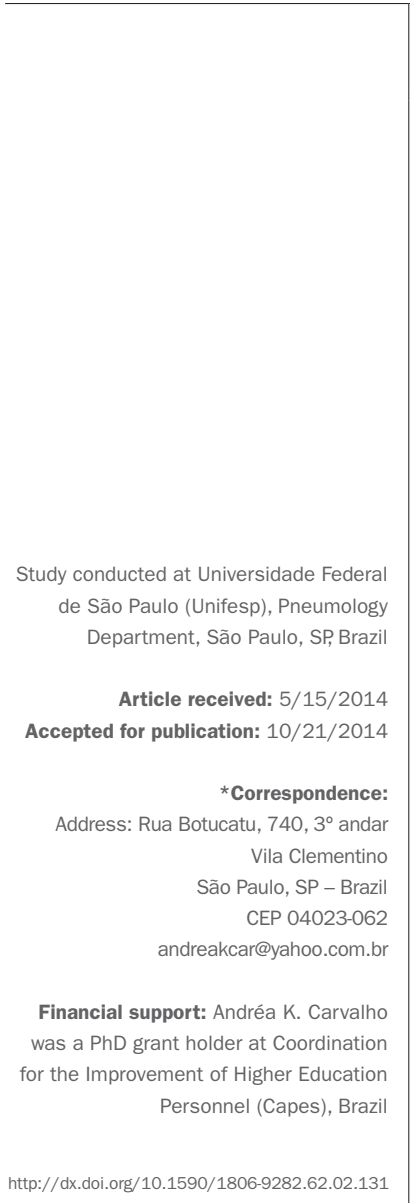

\section{SUMmARY}

Objective: To evaluate the sponsored centers for clinical trial in the respiratory care setting in Brazil: profile; logistics and structure.

Methods: Principal investigators (29) and subinvestigators (30) of 39 research centers completed the questionnaires that addressed personal identification and training of researchers, the centers' facilities and advantages and/or disadvantages of performing sponsored trials.

Results: $75.6 \%$ of the centers were located in southern and southeastern Brazil. Most principal investigators were men with a mean age of 53.4 years. The clinical trials in the respiratory care setting focus on asthma and chronic obstructive pulmonary disease (COPD). $80 \%$ of the researchers cited delay of the Conep and Anvisa as a barrier to performing research. The advantages of participating in clinical trials were updating knowledge of the researcher and the team, and additional income for the team. The main disadvantages mentioned by the researchers included low financial compensation for the performed workload, and time availability. The median number of professionals per research center was six people, predominantly physicians. Conclusion: The number of research centers in the respiratory care setting in Brazil is still relatively small. The teams have good training for performing the clinical trials. Asthma and COPD are the most studied diseases in sponsored clinical trials. The main barrier is delay by the Conep and Anvisa. The factors that lead investigators to participate range from being updated along with the team, to site and staff financial issues; the main disadvantage is the low compensation for the required workload demand.

Keywords: Biomedical research, drug industry, clinical trials as topic.

\section{INTRODUCTION}

Clinical research is a term that refers to investigations in humans regarding a specific therapy or new procedures, their effects, safety, tolerability and efficacy. These surveys are usually sponsored by pharmaceutical companies who have developed the new drug or procedure, and which manage the process of conducting research, or hiring specialized companies, called clinical research Organizations (CRO). The goal is to ensure that these studies meet the international standards recommended by regulators and controllers, according to the International Conference on Harmonization/Good Clinical Practice (ICH/GCP), ${ }^{1,2}$ the Good Clinical Practice Guidelines ${ }^{3,4}$ and the Document of the Americas elaborated by the Pan American Health Organization (PAHO). ${ }^{5}$

The first resolution on clinical research in Brazil was CNS Resolution 01/1988, demarcating the ethical aspects that should be followed for conducting research in the health sector in the country. ${ }^{6}$ It was followed by Resolution 196/1996, entitled Guidelines and Norms Regulating research Involving Human Beings. ${ }^{7}$

The exponential growth of clinical research in Brazil is undeniable, also in the area of pulmonology, creating a market that intertwines various aspects. This growth 
stems from greater awareness of the prevalence of respiratory diseases and chronic diseases in general $^{8}$ in the country and specifically in the respiratory area, as well as the number of new drugs that are being developed for asthma, ${ }^{9}$ chronic obstructive pulmonary disease, ${ }^{10}$ pulmonary fibrosis and pulmonary hypertension. ${ }^{11}$ Experience has shown that centers initially associated with sponsored clinical research, those sponsored by the pharmaceutical industry, have started to perform academic research. However, little is known about the teams and research centers that are involved in carrying out sponsored multicentric clinical research in pulmonology. Knowledge about the teams and pulmonology research centers in our country and their dissemination could encourage the creation of other centers.

The primary objective of this study was to delineate the profile of sponsored multicentric clinical research centers in the respiratory area in Brazil, assessing the physical constitution of these research centers and the training of professionals.

\section{Methods}

\section{Study design}

Two questionnaires were developed related to sponsored clinical research, one for the principal investigators and another for physicians acting as subinvestigators. As inclusion criteria, the respondents had to be a principal investigator and/or subinvestigator at a center working in the respiratory area. As this research would not cause any moral, financial or psychological harm, the research Ethics Committee (REC)/Unifesp (registration number 1044/09) advised that by simply answering the questionnaire the investigators implied that they agreed with the research, so a consent form was not required.

\section{Preparation of questionnaires}

The questions related to the identification, training of respondents, the premises of the centers and advantages and disadvantages regarding participation in sponsored clinical research were common to both questionnaires. Questions about the physical facilities of the center, the team's constituents and financial aspects were answered only by the principal investigators.

Most of the questions were closed. In addition to these, open questions were elaborated, which allowed the respondent to answer freely by giving their opinion. The principal investigator questionnaire contained 36 questions, 24 closed and 12 open, while the subinvestigator questionnaire contained 22 questions, 11 closed and 11 open.

\section{Questionnaires}

The participating principal investigators and subinvestigators received an electronic message with an invitation letter explaining the study. A link was provided that led to a page available on the Unifesp website, which contained the two questionnaires. Each investigator answered the questionnaire that was specific to them. Respondents sent the answers electronically, which were automatically stored in a database specifically developed for this research. The minimum sample size could not be calculated because this was a descriptive study. All of the pulmonologists who were principal investigators and subinvestigators at sponsored research centers working in the respiratory area in Brazil were invited from the list of centers specialized in conducting clinical research in the respiratory area from the Clinical Research Organizations (CROs) and sponsoring pharmaceutical industries. Data collection, including sending the invitation and link to the questionnaire, took place during the period between December 2010 and June 2011.

\section{Statistical analysis}

The numerical data is displayed as mean, median and standard deviation. The categorical data is arranged by number and percentage.

\section{ResuLts}

\section{Sample}

Thirty-nine centers were initially included. Twenty-nine principal investigators $(61.7 \%)$ and thirty subinvestigators $(57.7 \%)$ of a total of 43 principal investigators and 52 subinvestigators responded the questionnaires. Up to four attempts were made to contact researchers who did not respond to the first request. The overall non-response rate was $37.9 \%$. The predominant reason for not accepting the invitation was "lack of time to answer the questionnaire".

Characterization of the sample - characterization of clinical research centers

Given the total number of research centers, $55.1 \%$ are in the southeast and $20.6 \%$ in the south of Brazil. São Paulo leads with $37.9 \%$. The northeast and midwest regions represent only $10.3 \%$ and $3.4 \%$, respectively. The north region did not have a clinical research center working in the respiratory area in Brazil (Figure 1). Most of the research centers $(62 \%)$ operated in public teaching institutions $(24.1 \%)$ or public hospitals (37.9\%). 
Characteristics of the sample of principal investigators and subinvestigators

The demographic characteristics and training of researchers are shown in Table 1.

\section{TABLE 1 Characteristics of the sample of investigators} and subinvestigators of the study $(n=59)$.

\begin{tabular}{lll} 
Variables & $\begin{array}{l}\text { Principal investigators } \\
(\mathbf{n = 2 9 )}\end{array}$ & $\begin{array}{l}\text { subinvestigators } \\
\mathbf{( n = 3 0 )}\end{array}$ \\
\hline Age - years (SD) & $\mathbf{5 3 . 4 ( 8 . 0 )}$ & $\mathbf{3 7 . 4 ( 7 . 2 )}$ \\
\hline Age range - $\mathbf{n}(\mathbf{\%})$ & & \\
\hline $20-29$ & - & $2(6.7)$ \\
\hline $30-39$ & $2(6.8)$ & $19(63.3)$ \\
\hline $40-49$ & $7(24.2)$ & $8(26.7)$ \\
\hline $50-59$ & $12(41.4)$ & $1(3.3)$ \\
\hline $60-69$ & $8(27.6)$ & - \\
\hline Gender - $\mathbf{n}(\%)$ & & $11(36.7)$ \\
\hline Male & $20(68.7)$ & $19(63.3)$ \\
\hline Female & $9(31.3)$ & $13.1(7.6)$ \\
\hline Years of profession & $28.4(8.4)$ & \\
- years (SD) & &
\end{tabular}

\begin{tabular}{lll}
\hline \multicolumn{3}{l}{ Graduate diploma $-\mathbf{n}(\%)$} \\
\hline $\begin{array}{l}\text { Specialized in clinical } \\
\text { research * }-\mathrm{n}(\%)\end{array}$ & $9(24.1)$ \\
\hline Medical residency & $28(96.6)$ & $27(90.0)$ \\
\hline $\mathrm{MSc}$ & $18(62.1)$ & $11(36.7)$ \\
\hline $\mathrm{PhD}$ & $21(72.4)$ & $9(30.0)$ \\
\hline Post-doctoral & $11(37.9)$ & $3(10.0)$ \\
\hline $\begin{array}{l}\text { Professor/preceptor } \\
-\mathrm{n}(\%)\end{array}$ & $24(82.8)$ & $14(46.7)$ \\
\hline $\begin{array}{l}\text { Thesis supervision - } \\
\mathrm{n}(\%)\end{array}$ & $19(65.5)$ \\
$\begin{array}{l}\text { SD: Standard deviation. } \\
\text { *Continuing education in Good Clinical Practice (GCP) and/or short courses. }\end{array}$
\end{tabular}

Areas of greatest activity of the sponsored clinical research The areas of greatest activity in active research centers were asthma and chronic obstructive pulmonary disease (COPD), followed by oncology, infection, pulmonary circulation and interstitial diseases, respectively.

Difficulties reported for conducting sponsored clinical research in the respiratory area in Brazil

The researchers indicated the National Ethics and research Commission (Conep) and the National Health Surveillance Agency (Anvisa) as the main difficulties for conducting research, mainly in the "delay" item (Table 2). Difficulty of recruiting patients was also reported. With regard to the team, the main item was the required "time available".

TABLE 2 Difficulties reported for conducting clinical research in Brazil.

\begin{tabular}{|c|c|c|}
\hline Variables & $\begin{array}{l}\text { Principal } \\
\text { investigators } \\
(n=29)\end{array}$ & $\begin{array}{l}\text { subinvestigators } \\
(n=30)\end{array}$ \\
\hline Conep - n (\%) & $24(82.7)$ & $24(80.0)$ \\
\hline Delay & $22(91.6)$ & $24(100.0)$ \\
\hline Demands & $9(37.5)$ & $9(37.5)$ \\
\hline Lack of training & $6(25.0)$ & $6(25.0)$ \\
\hline Anvisa - n (\%) & $21(72.4)$ & $14(46.6)$ \\
\hline Delay & $19(90.4)$ & $14(100.0)$ \\
\hline Demands & $10(47.6)$ & $6(42.8)$ \\
\hline Lack of training & $5(23.8)$ & $2(14.3)$ \\
\hline CEP - n (\%) & $9(31.0)$ & $7(23.3)$ \\
\hline Delay & $9(100.0)$ & $5(71.4)$ \\
\hline Demands & $3(33.3)$ & $5(71.4)$ \\
\hline Lack of training & $2(22.2)$ & $1(14.3)$ \\
\hline Patients - n (\%) & $12(41.37)$ & $20(66.6)$ \\
\hline Difficulty recruiting & $9(75.0)$ & $15(75.0)$ \\
\hline Cognition & $8(66.6)$ & $9(45.0)$ \\
\hline Low adherence & $4(33.3)$ & $11(55.0)$ \\
\hline Illiteracy & $8(66.6)$ & $4(20.0)$ \\
\hline Center infrastructure & $2(16.6)$ & $8(40.0)$ \\
\hline Team - n (\%) & $11(37.9)$ & $8(30.0)$ \\
\hline Time availability & $9(81.8)$ & $5(55.5)$ \\
\hline Profession regulations & $6(54.5)$ & $3(33.3)$ \\
\hline
\end{tabular}

Note: In some of the variables, the sum of the sub-items may have a number of responses greater than the total number of investigators because they could respond to more than one item.

The main advantages in participating in clinical research indicated by principal investigator were "additional income for the team" and "funding for the center/institution”, both with $86.2 \%$.

\section{Characterization of the research center teams}

The questionnaire directed to principal investigators contained questions related to the characterization of their research center, including positions and professions existing at the center.

The median number of professionals by research center was six people, with a percentile of $25 / 75 \%$ for $4 / 6$ persons, and predominantly physicians.

Of the total of 40 research coordinators reported, the highest proportion was that of physiotherapists (32.5\%), even though they were not in greater numbers. In research 


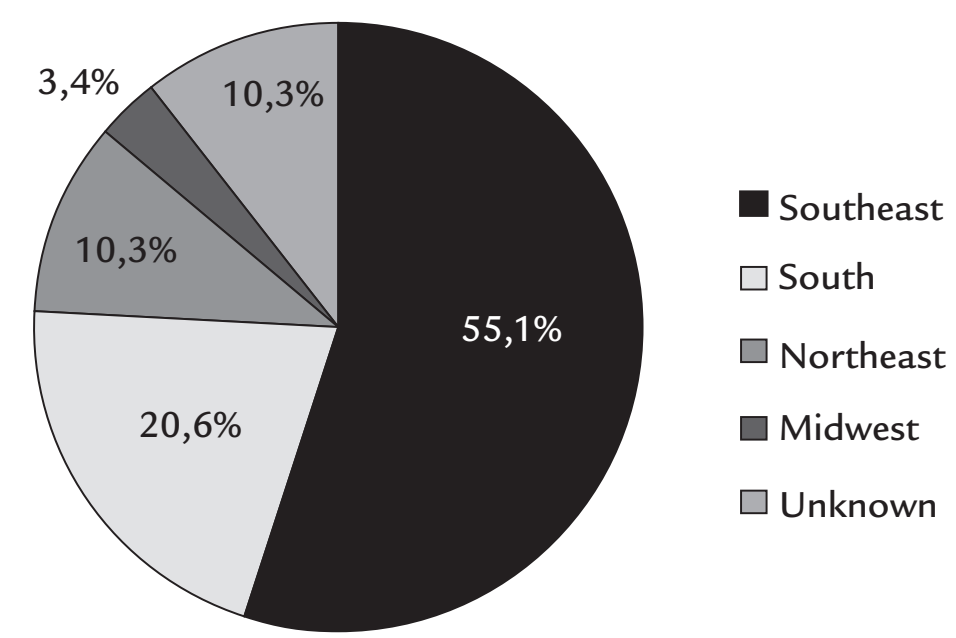

FIGURE 1 Characterization of clinical research centers per region in Brazil.

assistance, five of the 13 professionals (38.5\%) were nurses and three $(23.1 \%)$ were pharmacists.

\section{Discussion}

This assessment has shown that there are still few active research centers in Brazil in the respiratory area compared with the international context. However, the centers are relatively well structured in relation to basic infrastructure, and the academic training of the team involved is good. The main obstacles to research are external to the center, and are associated with authorities such as the Conep and Anvisa, due to delay in the analysis and clearance of projects. The factors that lead the centers to do research are multiple, including updating the knowledge of the team, finance and links to other research centers. Lastly, we found that the main disadvantages are the limited time availability and low payment offered by the industry for conducting clinical research.

While sending the questionnaire, we observed the existence of a small number of active research centers in our country in the area of respiratory medicine compared to the number of research centers in Europe, the United States and even other countries in Latin America, such as Argentina, which presented a greater number of centers at the time. In addition, these centers were concentrated in the southeast and south regions of the country, with only two centers in the northeastern region, in the states of Bahia and Pernambuco, and one in the midwest, in the state of Goiás. This disparity demonstrates the low interest in clinical research in the other regions of the country, which apparently has a direct relation with not conducting research in general, as well as poor promo- tion of the research practice and of all the advantages to both the professional involved and the research institution. We did not find references to the research centers operating in the respiratory area in Brazil in publications from the United States or Europe; however, in the Torch Study, ${ }^{12}$ which evaluated the survival of 6,000 patients with COPD by comparing the use of salmeterol and fluticasone in association or individually, there was a participation of 184 US centers and 156 European centers, compared with 10 centers in Latin America, seven from Brazil and three from Argentina. In the Uplift Study, ${ }^{13}$ that monitored the progression of the pulmonary function in six thousand COPD patients for four years, with and without the use of tiotropium, 96 centers in the United States took part, as well as 293 centers in Europe, and in Latin America, only Brazil and Argentina participated in this study with 10 and 15 centers each, respectively. These figures demonstrate that there are still few research centers in Latin America compared to Europe and the United States.

We believe that the predominance of male investigators has no direct relation to clinical research, and is a characteristic of this particular sample. The principal investigators have more years of training than the subinvestigators, because, having worked longer in both the clinical practice and the academic area, they are more recognized professionally and, thus, more often invited to contribute by the industry.

The principal investigators and subinvestigators mostly have a good level of training, and are directly or indirectly involved with academic research. We observed that the professionals involved in conducting sponsored clin- 
ical research are well qualified. They are scholars by choice and, to a certain extent, form a basis for the good conduction of clinical research.

The areas cited more frequently were COPD and asthma, which is understandable, as they are the most common diseases in the respiratory area and generate greater financial returns, often becoming the industry's focus for investment in studies.

At the ClinicalTrials.gov website, a service from the US National Institutes of Health comprising a registry and database of the results of private and public studies being performed throughout the world, the results corroborate those found in our study. ${ }^{14}$ Obstructive pulmonary diseases occupy the top position in the ranking of diseases studied, with 3,116 articles registered, as well as asthma with 1,869 studies, and COPD with 1,313 studies. The ClinicalTrials.gov website was accessed in February 2012 for the purpose of this article.

Despite the good training of the teams and the professionalism in conducting studies, there are external barriers to conducting clinical research in Brazil. For the investigators, the Conep and Anvisa lead the ranking of these difficulties, especially for the delay in the release of opinions. Although not cited by our sample, to be fair, it is worth pointing out that we also have to account for possible "internal barriers", that is, those inherent to research centers, such as incomplete dossiers and regulatory documents completed incorrectly. These facts are often reported by officers of the Conep and Anvisa in meetings discussing the researcher/Conep/Anvisa relationship.

The Brazil platform launched in January 2012 and seen as an achievement is a national, unified database of research records involving humans for the entire CEP/ Conep system. It allows the follow-up of studies at different stages, from submission to final approval by the CEP and Conep. Documents are presented digitally in this system. One advantage of this system is that it allows access to everyone involved in the research, regardless of the location of the centers, and the Brazil Platform intends to significantly reduce project processing time throughout the CEP/Conep system. ${ }^{15}$

Once aware of the difficulties faced in clinical research, as discussed above, it was important to understand what leads an investigator to become interested in conducting clinical research in Brazil. An interesting point is that we expected our sample to cite more openly the advantages related to the benefits of clinical research for patients, but this only occurred in $45 \%$ of our sample. In areas such as oncology and inflammatory diseases, patients who par- ticipate in studies for new drugs for their illnesses benefit from it, because sometimes there is still no other therapy available; ${ }^{16}$ Danesi and Goldbaum ${ }^{17}$ point out that "about two billion people in the world are in need of essential drugs", which should be the responsibility of the State, although the pharmaceutical industry shares this responsibility through the development of new drugs which, in its own way, has contributed to advances in the quality of life of patients. ${ }^{17}$ However, the main attractions indicated by the researchers in our sample were: updating their knowledge and that of the team involved, additional income for the team, maintaining ties with national and international industry, funding for the center/ institution, ties with international research centers and access to medication and devices not available in Brazil. The factors above were cited more than $65 \%$ for each sample, including principal investigators and subinvestigators, given that the two most significant citations were "additional income for the team" and the "funding for the center/institution", both with $86.2 \%$, as shown in the results. This data exposes the Brazilian reality of low funding and limited support for Scientists involved with research in general. Thus, sponsored clinical research has become a means of keeping a team that likes sponsored research, but that also conducts academic research, and which has in such work, in addition to the financial support, the possibility of access to knowledge, medication and devices that are unlikely to be available in Brazilian public health care and professional training institutions.

However, there are disadvantages to this participation, as confirmed by the Investigators. The main disadvantage is the demand for time and involvement of these professionals, given the standardization and national and international rules that permeate the development of research, and the low financial compensation received in face of the demands of the work, that is, what is left for payment of the principal investigator after deducting the total cost of the research Center. It is not uncommon to find large disparities between national and international budgets, generating lower income for national centers and lower pay for researchers, who supplements their income with other activities parallel to the research. It is worth reiterating that opening a research center in Brazil can be more expensive, depending on its location. In Europe and especially in the US, non-investigational exams and medication are reimbursed by health insurance, while in Brazil the companies usually charge for everything. More recently, the issue of supplying medication after the end of the research has also been adding costs that other countries do not face. Also, in Brazil, research- 
ers/research center managers must do their own cost studies, thereby basing their discussion with the industry on the negotiation of contracts.

In the characterization of the participating team, we observed that the centers are already well-developed with regard to human resources, with an average of six people on the team, when commonly a research center starts with only three people. What we observed is that the increase in projects requires more professionals to assume the positions of Coordinators, research Assistants, and subinvestigators, increasing the capacity for work when conducting research. As expected, there is a larger proportion of physiotherapists as study coordinators. We suppose that this occurs due to the nature of their specialty, which commonly treats patients in specialist respiratory outpatient clinics working together with physicians. This ends up characterizing the teams in research centers, with physicians and physiotherapists in the positions of principal investigators and coordinators, respectively. We also noted that, in the practice of clinical research, teams are formed based on familiarity, convenience and affinities.

\section{LIMITATIONS OF THE STUDY}

From the beginning, we intended to use the same questionnaire to know the opinion of non-specialists in the respiratory medicine and other physicians who do not participate in this type of research (from the same cities of the researchers) on sponsored clinical research. We requested the principal investigators interviewed in our research to indicate a clinician known to them and when contacting them we made reference to such indication. Unfortunately, even with this we had a very low return of the 26 questionnaires sent and re-sent three times again. Given that we received only three responses, we decided not to draw any conclusions from these questionnaires.

This is the first study assessing the panorama of clinical research conducted in the respiratory area in Brazil. From this information we were able to portrait the structure of these centers, the level of training of the participating professionals and the losses and gains derived from this participation. It would be very interesting in the future to conduct the same search in other areas of medicine, which would provide a chance to understand more fully sponsored clinical research in Brazil.

This data allows us to affirm that it is possible to invest in greater professionalization in this area, and we can no longer ignore the fact that clinical research has become another possibility of working with good direct and indirect gains for the professionals involved and for so- ciety in general. It is worth mentioning that over the years some companies have created research courses with the goal of leveraging training in the clinical research area. ${ }^{18}$ However, at professional congresses of the clinical research area held by the Brazilian Society of clinical research Professionals (SBPPC), we have noted that interest in these courses has recently been falling, probably due to the decrease of research center teams as a result of internal and external obstacles in the regulatory process for conducting clinical trials.

\section{Conclusion}

There are few centers in Brazil in the respiratory area conducting sponsored research; the teams comprise professionals with satisfactory training; the external barriers are mainly associated with the higher regulatory instances, the Conep and Anvisa. There are advantages that encourage investigators to participate in clinical research: updating their knowledge and that of the team involved, additional income for the team, national and international links with industry, funding for the research center or institution where it is located and, lastly, maintaining and/or creating links with international research centers. Nevertheless, there are disadvantages, such as the demands of the work associated with insufficient budgetary remuneration.

\section{Resumo}

Pesquisas clínicas multicêntricas patrocinadas realizadas na área respiratória no Brasil - Perdas e ganhos

Objetivo: avaliar nos centros de pesquisas clínicas patrocinadas na área respiratória no Brasil o perfil, a logística e a estrutura.

Método: questionários foram respondidos por pesquisadores principais (29) e subinvestigadores (30) de 39 centros de pesquisa relativos a identificação e formação dos pesquisadores, instalações dos centros e vantagens e desvantagens quanto à participação nas pesquisas patrocinadas.

Resultados: setenta e cinco por cento (75,6\%) dos centros se localizavam nas regiões Sul e Sudeste do Brasil. A maioria dos investigadores principais eram homens com média de idade de 53,4 anos. As pesquisas na área respiratória se concentravam no estudo da asma e da doença pulmonar obstrutiva crônica (DPOC). Oitenta por cento dos pesquisadores citaram a demora na Comissão Nacional de Ética em Pesquisa (Conep) e na Agência Nacional de Vigilância Sanitária (Anvisa) como fator de entrave para a realização das pesquisas. As vantagens em 
participar das pesquisas clínicas foram a atualização própria ou da equipe envolvida, com rendimento adicional para a equipe. A principal desvantagem apontada pelos pesquisadores foi a baixa compensação financeira em relação ao volume de trabalho e disponibilidade de tempo. A mediana de profissionais por centro de pesquisa foi de seis pessoas, com predominância de médicos.

Conclusão: o número de centros na área respiratória no Brasil ainda é relativamente pequeno. As equipes apresentam boa formação para a realização das pesquisas. Asma e DPOC são as doenças mais estudadas pelas pesquisas clínicas patrocinadas. O principal entrave é a demora da Conep e da Anvisa. Os fatores que levam os investigadores a participarem variam desde atualização própria/equipe até questões financeiras para a equipe e o centro; a principal desvantagem relatada é a baixa remuneração diante da demanda de trabalho exigida.

Palavras-chave: pesquisa biomédica, indústria farmacêutica, ensaios clínicos como assunto.

\section{RefEREnCES}

1. International Conference on Harmonisation of Technical Requirements for Registration of Pharmaceuticals for Human Use. [cited 2014 Mar 16] Available from: http://www.ich.org/home.html.

2. World Health Organization. WHO. Guidelines for good clinical practice (GCP) for trials on pharmaceutical products. WHO Technical Report Series, n. 850, annex3. 1995 [cited 2014 Mar 16]. Available from: http://www.nus. edu.sg/irb/Articles/WHO\%20GCP\%201995.pdf.

3. Zago MA. A pesquisa clínica no Brasil. Ciência Saúde Coletiva. 2004; 9(2):363-74
4. European Federation of Pharmaceutical Industries and Associations. Promotions of medicines. [cited 2014 Mar 16]. Available from: http://www. efpia.eu/Content/Default.asp?PageID $=150$.

5. Boas Práticas Clínicas: documento das Américas. Organização Panamericana de Saúde, Organização Mundial de Saúde, Rede Panamericana para Harmonização da Regulamentação Farmacêutica. [cited 2014 Mar 15] Available from: http://www.invitare.com.br/.

6. European Public Health Alliance. Gifts from the pharmaceutical industry: to accept or not to accept? [cited $2011 \mathrm{Feb} 4$ ]. Available from: http://www. epha.org/a/2112.

7. American Medical Student Association. National Pharm Free Day. [cited 2011 Jan 31]. Available from: http://www.amsa.org/prof/pharmfree.cfm.

8. Carvalho AK, Menezes AMB, Camelier A, Rosa FW, Nascimento OA, PerezPadilla R, et al. Prevalence of self-reported chronic diseases in individuals over the age of 40 in São Paulo, Brazil: the PLATINO Study. Cad Saúde Pública. 2012; 28(5):905-12.

9. Strachan DP, Sibbald B, Weiland SK, Ait Kaled N, Anabwani G, Anderson HR et al. Worldwide variations in prevalence of symptoms of allergic rhinoconjunctivitis in children: the International Study of Asthma and allergies in Childhood (ISAAC).Pediatr Allergy Immunol. 1997; 8(1):161-76.

10. Menezes AMB, Perez-Padilla R, Jardim JR, Muiño A, Lopez MV, Valdivia G, et al.; PLATINO Team. Chronic obstructive pulmonary disease in five Latin American cities (the PLATINO study): a prevalence study. Lancet. 2005; 366(9500):1875-81

11. Williams B. The year in hypertension. J Am Coll Cardiol. 2010;55(1):66-73

12. Calverley PM, Anderson JA, Celli B, Ferguson GT, Jenkins C, Jones PW, et al.; TORCH investigators. Salmeterol and fluticasone propionate and survival in chronic obstructive pulmonary disease. N Engl J Med. 2007; 356(8):775-89.

13. Tashkin DP, Celli B, Senn S, Burkhart D, Kesten S, Menjoge S, et al.; UPLIFT Study Investigators. A 4-year trial of tiotropium in chronic obstructive pulmonary disease. N Engl J Med. 2008; 359(15):1543-54.

14. ClinicalTrials.gov. National Institute of Healthy. [cited 2012 Feb 18]. Available from: http://www.clinicaltrials.gov/.

15. Plataforma Brasil - Publicação da Conep (Comissão Nacional de Ética em Pesquisa). [cited 2012 Feb 18]. Available from: www.saude.gov.br/plataformabrasil.

16. Rizzo LV, Camargo LFA. Pesquisa clínica no Brasil. Einstein (São Paulo). 2013; 11(1):7-8.

17. Dainesi SM, Goldbaum M. Pesquisa clínica como estratégia de desenvolvimento em saúde. Rev Assoc Med Bras. 2012; 58(1):2-6.

18. Invitare Pesquisa Clínica. [cited 2014 Mar 17]. Available from: www.invitare. com.br. 